\title{
The Effect Of Health Education Using Audiovisual Media (Video) on Knowledge Basic Life Support (BLS) About Cardiopulmonary Resuscitation (CPR) (Study on Students of SMK 1 Banjarbaru)
}

\author{
Amalia Septiani ${ }^{1 *}$, Abdurahman Wahid ${ }^{2}$, Herry Setiawan ${ }^{3}$ \\ \{ amaliasept09@gmail.com $^{1}$, ns.wahid@unlam.ac.id ${ }^{2}$, setiawanherry4444477@ gmail.com $\left.{ }^{3}\right\}$ \\ ${ }^{1}$ Student of Nursing Study Program Faculty of Medicine Lambung Mangkurat University, Indonesia \\ ${ }^{2}$ Department of Nursing Emergency Department Nursing Studies Program Faculty of Medicine, \\ University of Lambung Mangkurat, Indonesia \\ ${ }^{3}$ Department of Nursing Management Nursing Science Study Program Faculty of Medicine, University \\ of Lambung Mangkurat, Indonesia \\ *amaliasept09@gmail.com
}

\begin{abstract}
The importance of Basic Life Support (BLS) about Cardiopulmonary Resuscitation (CPR) was closely related to Out of Hospital Cardiac Arrest (OHCA), because more and more people who know this action can reduce the disability and mortality rate of OHCA. However, cardiac arrest event can be handle with Basic Life Support (BLS) about Cardiopulmonary Resuscitation (CPR). In SMKN 1 Banjarbaru never been a health education on BLS measures about CPR. This research used pre-experimental with pre-post test design approach, collection data technique that use probability sampling with simple random sampling type approach and sample this numbers of 42 respondent. Instrument used in the form of questionnaires knowledge CPR. Research Result get value ( $\mathrm{p}$-value $=0,000<\alpha=0,05$ ) on student knowledge. This show effect of health education using audiovisual (video) on BLS knowledge about CPR in SMKN 1 Banjarbaru students.
\end{abstract}

Keywords: Knowledge, Audiovisual (Video), Basic Life Support (BLS), Cardiopulmonary Resuscitation (CPR)

\section{Introduction}

Every year there are more than 36 million people die due to Non-Communicable Diseases (PTM), which is around 63\% of all deaths . The occurrence of cardiac arrest outside the hospital or called the Out of Hospital Cardiac Arrest (OHCA) is the main cause of PTM deaths in some developing countries [1]. OHCA incidents according to the American Heart Association (AHA) (2015), namely in 2012 were 382,800, 2013 were 359,400, 2014 were 424,000, and 2015 were 326,200 [2].

If the death occurs due to the inability of health workers to handle during the emergency phase (golden period). P ertolongan to do is Basic Life Support (BLS) / Assisted Living Association (BHD) on Cardiac Pulmonary Resuscitation (CPR) [3] . According to the American Heart Association (AHA) (2015), RJP can be done by all people who know the action. One of the nurses' roles is as an educator, namely providing education or about BLS actions regarding RJP [2] .

Based on research conducted by Sri Haryuni and Wiwin Sulistyawati (2017), said that audiovisual can help in the implementation of health education about BLS regarding RJP [4] . In line with research conducted by the Official Pangaribuan, Mindo Tua Siagian and Asima Sirait (December 2017 - May 2018), it was said that video selection as a medium for health education was well received by respondents from counseling using audiovisuals that 
display motion, images and sound, so that it can make respondents feel more interested and enthusiastic [5].

Based on preliminary studies were done of the first data request to the South Kalimantan Provincial Education Department regarding the number of high school / vocational equivalent in Banjarbaru, d idapatkan the result that the data of the high school / vocational equivalent in Banjarbaru there are 23 schools. The second preliminary study was interviewed with the Deputy Principal of SMKN 1 Banjarbaru and the students of SMKN 1 Banjarbaru. The results obtained have not been done BLS health education about CPR and on average students do not yet know about BLS action regarding CPR .

\section{Research Methods}

This research is a pre-experimental study using the on e- group pre-post test design approach [6] . The population in this study were, XI students of SMKN 1 Banjarbaru, totaling 84 students, who were numbered from 3 (three) XI classes. The samples in this study are, students of class XI SMK 1 Banjarbaru, with the process of sampling using simple random sampling technique [7].

The instrument in this research is, using audiovisual media in the form of video, BLS knowledge questionnaire about CPR.S oal with multiple choice answers, the answers are worth 10 (ten) if the answer "right" and is 0 (zero) if the answer is "wrong". The analysis used is univariate analysis which includes class, gender, age, pre-test and post-test. In this study, also using bivariate analysis that use Wilcoxon. At the time the study points to consider in ethics anya namely, the consent form (informed consent), no name (anonimity), confidentiality, fairness (justice), ethical clearance [8].

\section{Results and Discussion}

Table 1. Distribution of Number and Percentage of Characteristics of Respondent Classes in Class XI of SMKN 1 Banjarbaru

\begin{tabular}{ccc}
\hline Class & N & Percentage (\%) \\
\hline XI Ceramic Craft & 14 & 33.3 \\
\hline XI Textile Craft & 14 & 33.3 \\
\hline XI Metal Crafts & 14 & 33.3 \\
\hline Total & 42 & 100.0 \\
\hline
\end{tabular}

Based on table 1 it is known that the number of respondents in each class is the same as the number of $14(33.3 \%)$ respondents in each class. The reason for taking the XI grade of SMK is because it is related to the elaboration of Notoadmojo (2012) which revealed that a high level of education is better than a low level of education in terms of knowledge possessed by someone [9]. 
Table 2. Distribution of Number and Percentage of Gender Characteristics of Respondents in Class XI SMK 1 Banjarbaru

\begin{tabular}{ccc}
\hline Gender & N & Percentage (\%) \\
\hline Male & 9 & 21.4 \\
\hline Girl & 33 & 78.6 \\
\hline Total & 42 & 100.0 \\
\hline
\end{tabular}

Based on table 2, it is known that the majority of respondents' gender is female with a total of $33(78.6 \%)$ respondents. This is because in each class there are more women than men. Based on the presentation Fuadbahsin (2009) states that gender is not a thing that can affect a person's knowledge, because whatever the gender if the person is still productive, has broad insight, and has a great experience then it can affect the knowledge owned by someone ( 10$)$.

Table 3. Age Characteristics of Respondents in Class XI SMK 1 Banjarbaru

\begin{tabular}{cccccc}
\hline Variable & The mean & Median & Min-Max & Elementary school & 95\% CI \\
\hline Age & 17.07 & 17.00 & $17-18$ & 0.26 & $\begin{array}{c}16.99- \\
17.15\end{array}$ \\
\hline
\end{tabular}

Based on table 3 it is known that the average age of the respondent is 17 years old with the median age of the respondent being 17.00. According Widyastuti (2009) based on the nature and characteristics of adolescent development can be categorized into 3 (three), namely, early adolescents (10-12 years), middle adolescents (13-15 years) and late adolescents (16-19 years) [11]. In accordance with the results of the study, it is known that the average respondent is 17 years old which shows that age does not affect the respondent's knowledge, because the age of all respondents is in the late adolescent category. Closely related to the presentation of Sarwono (2006) which states that at the age of adolescents have a high level of curiosity and have a broader ability to think in terms of insight [12].

Table 4. Students' Knowledge Before and After Screening of the BLS Video about RJP for Students of SMKN 1 Banjarbaru

\begin{tabular}{cccccc}
\hline Variable & $\begin{array}{c}\text { The } \\
\text { mean }\end{array}$ & Median & Min-Max & $\begin{array}{c}\text { Elementary } \\
\text { school }\end{array}$ & 95\% CI \\
\hline $\begin{array}{c}\text { Knowledge before video } \\
\text { screening (pre-test) }\end{array}$ & 26.67 & 30.00 & $0-50$ & 13,19 & $\begin{array}{c}22.56- \\
30.78\end{array}$ \\
\hline $\begin{array}{c}\text { Knowledge after video } \\
\text { display (post-test) }\end{array}$ & 85.48 & 88.72 & $70-100$ & 10,41 & $\begin{array}{c}82.23- \\
82.21\end{array}$ \\
\hline
\end{tabular}

Based on table 4 it is known that prior to the BLS video display on RJP in class XI students of SMKN 1 Banjarbaru, knowledge results obtained with an average score of 26.67 with a median of knowledge before video screening (pre-test) was 30.00. This can occur due to the lack of BLS information on CPR so that respondents do not know well the information submitted. This can also be caused by the absence of a program from the school or the school does not have a program related to BLS actions regarding RJP .

According to research conducted by Hengki Tamando Sitohang (2018) states that information is obtained but has been processed into a form that is more useful for those who 
receive [13] . According to Notoatmodjo (2007) information is a factor that can give effect to one's knowledge, so that knowledge can be obtained through the information obtained. The information that has been obtained can be used as a foundation and a useful reference for instilling and growing knowledge about a matter obtained [14].

Lack of or lack of experience in helping cardiac arrest events outside the hospital can trigger a lack of knowledge about BLS regarding CPR, and this can be seen from the results of the questionnaire answers that have been filled out by respondents. Knowledge about BLS about RJP is very important for respondents to know, so that when respondents know and understand from these actions they can apply it when there is a cardiac arrest event, as explained by Notoadmojo (2007) regarding one understanding of the level of knowledge that is understanding (comprehension) which can be interpreted that if someone is able to explain an object or certain things that are known correctly and the material can be interpreted and appropriate so that it can be applied [14].

In line with research conducted by Megawati et al (2018) states that the knowledge and attitudes before getting intervention expressed low or lack of it is due to pengetahua $\mathrm{n}$ is the result of know what happened after ses e people do a Pengi nderaan against a particular object [15].

The results of this study are in line with research conducted by Sri Haryuni and Wiwin Sulistyawati (2017) who explained that the ability of students' live saving before receiving training using audiovisual methods (video) can be said to be low, this is due to the lack of health education obtained to support or encourage knowledge and skills about RJP [4]. Based on table 4 it is also known that after showing BLS video about RJP to class XI students of SMKN 1 Banjarbaru the respondents' knowledge was obtained with an average score of 85.48 with a median of knowledge after video screening (post-test) was 88.72 .

Increased knowledge of respondents can occur because when conducting research respondents looked enthusiastic and listened and listened to what was explained and what was explained by researchers. In this study, although respondents were dominated by female gender, this did not affect the knowledge of respondents, because in this study it was not found that there was an influence of gender on respondents' knowledge. It seems the same thing at the age of respondents in this study, that there is no effect of age on the knowledge of respondents, this can occur because the age of all respondents included in the category of late adolescents.

The purpose of health education is to establish a problem and be able to understand what to do with the problem with the various available resources so as to be able to decide on an appropriate action [16]. In line with research conducted by Tika Fajar and Yuni Purwati (2015) which states that counseling can facilitate the exchange of information and can be done with many people, one of the factors that can influence the success of health education is the media used during counseling [17]. The use of audiovisual media (video) in the implementation of health education according to Harjanto (2010) has many advantages, namely, can train someone in developing abstract imagination and someone can actively participate and foster attraction to attract attention, so as to foster enthusiasm and make someone will more enthusiastic [18].

In line with research conducted by Bayu Rahmadani (2016) which states that the use of audiovisual media can improve learning outcomes of students during learning, this shows that the use of audiovisual media can be used as one of the alternative learning media that can be applied [19]. According to research conducted by Akhmad Busyaeri, Tamsik Udin and A. Zaenuddin (2016) states that the results of research into the use of audiovisual media in the 
form of a video of knowledge is learning Natural Sciences showed that respondents strongly agreed to use video as a learning tool [20].

The results of this study are in line with research conducted by Sarfia Buamona, Lucky T. Kumaat and Regius T. Malar a (2017) which shows that from the measurement of the level of knowledge after the intervention provides an increase, this shows that the response that has been given health education about BLS/BHD in traffic accidents are able to understand well and are expected to be able to apply to the surrounding environment [21].

Table 5 . The Effect of Health Education Using Audiovisual Media (Video) on BLS Knowledge Regarding RJP in Students of SMKN 1 Banjarbaru

\begin{tabular}{cccccc}
\hline Knowledge & Mean & $\begin{array}{c}\text { Elementary } \\
\text { school }\end{array}$ & Min-Max & Mean Difference & p-value \\
\hline Pre-test & 26.67 & 13,19 & $0-50$ & \multirow{2}{*}{58.81} & 0,000 \\
\hline Post-test & 85.48 & 10.41 & $70-100$ & & \\
\hline
\end{tabular}

Based on the above table, it is known that after testing for statistical tests using the Wilcoxon test, a p-value of 0,000 (with a p-value of $0,000<\alpha=0.05$ ) shows that Ho is rejected and $\mathrm{Ha}$ is accepted. So from this explanation, it can be concluded that there is a significant influence between the pre-test of BLS knowledge about RJP and the post-test of BLS knowledge about RJP in SMKN 1 Banjarbaru students.

This can happen because during health education many respondents were asking questions and wanted to know about BLS regarding CPR, and made respondents become enthusiastic or actively involved during health education using audiovisual media (video), so that health education activities about BLS about CPR can be applied in schools or wherever possible to carry out this activity in order to help in increasing knowledge and insight about BLS about RJP.

This is also in line with the purpose of health education, which includes changes in attitudes and behavior of individuals, families, special groups, and the community in terms of fostering and maintaining healthy living behaviors and being able to realize more optimal health status [22]. According to Notoatmodjo (2010) also explained that the change in knowledge is influenced by a learning process that occurs, because knowledge is obtained from personal experience felt by someone [23].

The results of this study are in line with the official research of Pangaribuan, Mindo Tua Siagian and Asima Sirait (2018), who stated that there is an increase in nursing knowledge after being given health education with audiovisual media, this can occur because it is influenced by the provision of material provided namely BHD [5].In line with research conducted by A'an Dwi et al (2018) explained in the results of the study showed that from the use of audiovisual media (video) about Cardiopulmunal Resucitation (CPR) the results were effective in increasing the ability of the community which includes knowledge, attitudes and actions in carrying out CPR [24]. According to research conducted by Akhmad Busyaeri, Tams ik Udin and A. Zaenuddin (2016) stated that student learning outcomes using audiovisual media in the form of videos in learning at the time of delivery of the material found that the average learning outcomes occurred a drastic increase, this can occur due to the influence of the media used in conveying material during the learning process. This shows and proves that the high level of influence of video on student learning outcomes [20].

According to research conducted ol er Siti Masfiah et al (2017) which states that the use of audiovisual media in the form of a video at the time of health education can 
provide increased knowledge for respondents [25]. Media learning in the form of video is one of the electronic media that dynamic can be seen and heard in terms of delivering the message [26]. According to Rusman (2012) explains some of the advantages possessed by audiovisual media (video) in its use during learning and during health education namely, audiovisual media (video) can provide messages and feedback that can be well received by someone, the use of audiovisual media ( video) is very superior to explain and describe a process so that it can help when activities take place, and audiovisual media (video) in its application is more realistic or more real and can be repeated or stopped as needed, and audiovisual media (video) is able to give the impression depth that can affect one's knowledge and attitude when receiving or something through audiovisual media (video) [27].

In line with research conducted by Nurdyansyah (2017) which states that the learning model using audiovisual electronic media in the form of video is very well used in helping the learning process take place, especially to emphasize material that is very important to know by someone. This is closely related to the learning model innovation that uses video media in providing direction related to something that must be observed during the activity and the video can be played back according to the needs of the activity, and video media is a medium that can develop in accordance with technological improvements [28].

\section{Research Limitations}

The limitation in this study is that the measurement tools used in this study are in the form of a questionnaire so that the truth of the data is highly dependent on the focus of the respondent during the implementation of health education and honesty when answering the questionnaire about BLS knowledge about CPR. So you can use the observation sheet to make an assessment .

\section{Conclusion}

The conclusions in this study are as follows:

a. The knowledge level of the students of SMK 1 Banjarbaru s Before the dilakukan $\mathrm{p}$ Education k poor living conditions Health BLS about CPR using audiovisua media 1 (video) in the category less the percentage $<56 \%$ (score $1-5$ ) as many as 42 people.

b. The knowledge level of the students of $\quad$ SMK 1 Banjarbaru s e have d ilakukan $\mathrm{p}$ Education $\mathrm{k}$ poor living conditions Health BLS about CPR using audiovisua media 1 (video) in the category of simply the percentage of $56-75 \%$ (score 6-7) as many as 7 people and good with percentages 76$100 \%$ (score $8-10$ ) as many as 35 people.

c. The provision of health education using audiovisual media (video) influences the BLS knowledge of RJP 1 Banjarbaru students, this is stated by the exposure of data from the results of an analysis of knowledge enhancement that shows the significance value of p-value 0,00 . 


\section{Suggestion}

a. Next Research

Suggestions that can be given to further researchers is to provide BLS health education regarding CPR that can be done to other educational institutions in order to increase knowledge about BLS regarding good and correct CPR according to the latest protocol. The target of research carried out in educational institutions can be targeted at school principals and teachers not only at students, so BLS on CPR can be included in programs in these educational institutions.

b. For Respondents

Suggestions that can be given for respondents are that they can dig deeper related to first aid, especially related to BLS regarding CPR and can apply the knowledge gained when looking at cardiac arrest events that occur outside the hospital.

c. For Nursing Education

Advice can be given for nursing education that can make the results of this study as a reference for information material to increase knowledge in nursing services and as a reference for nursing services.

d. For Schools

Suggestions that can be given to schools are developing BLS on CPR so that they are able to be studied and applied in the school environment, as can be included in one of the important actions that exist in the Youth Red Cross (PMR) and on School Health Enterprises (UKS), so BLS on CPR can be one of the programs in school .

\section{References}

[1] Ministry of Health of the Republic of Indonesia. Data and Information Center. (2012).

[2] American Heart Association (AHA). Basic Life Support: updated guidelines for CPR and ECC. (2015).

[3] Dahlan, S. Nursing Science Study Program, Faculty of Medicine, Sam Ratulangi University. Manado. Journal of Nursing. (2014).

[4] Haryuni S, Wiwin S. Differences in Effectiveness of the Audiovisual Basic Life Support (BLS) Health Demonstration Method with Demonstrations on Life Saving Abilities in Nursing Students of FIK University Kadiri. Journal of Nursing Care and Biomoleculer. (2017).

[5] Remi P, Mindo Tua Siagian, Asima Sirait. The Influence of Health Education Media on Basic Life Assistance Knowledge (BHD) (Experimental Study on Implementing Nurses at TK Putri II Hospital, Medan Hijau, 2017). Student Journal and Health Research. (2018).

[6] Nursalam. Nursing Science Research Methodology. Practical Approach. Issue 3. Salemba Medika. Jakarta. (2013).

[7] Sugiono. Qualitative R\&B Qualitative Research Methods . Alfabeta. Bandung. (2015).

[8] Musafaah, Rudi F. Biostatistics Module . Nursing Science Study Program, Faculty of Medicine, Lambung Mangkurat University. (2017).

[9] Notoatmodjo S. Concepts of Behavior and Health Education. Rineka Cipta. Jakarta (2012).

[10] Fuadbahsin. Knowledge Theory and Influencing Factors. Jakarta. (2009).

[11] Widyastuti Y, et.al. Reproductive Health . Fitramaya. Yogyakarta. (2009).

[12] Sarwono SW. Adolescent Psychology. PT Raja Grafindo Persada. Jakarta. (2011). 
[13] Sitohang HT. Web Based Letter Management Information System at Medan High Court. Journal of Informatic Pelita Nusantara. (2018).

[14] Notoatmodjo S. Health Promotion and Behavioral Sciences. Rineka Cipta. Jakarta. (2007)

[15] Megawati, Syria, Rusli N, Ahmad Y. Education of Pulmonary Knowledge of the Posyandu Cadre's Attitude through Monopoly Simulation Games. MPPKI. (2018).

[16] Mubarak WI \& Chayatin N. Introductory Community Nursing and Book Theory 1 , Pages: 257-258, Salemba Medika. Jakarta. (2009).

[17] Dawn T. The Effects of Reproductive Health Counseling through Audio Visual Media on the Level of Knowledge and Attitudes About Pregnancy for Unmarried Adolescents at SMK 17 Bantul Yogyakarta 2015. (2015).

[18] Harjanto. Teaching Planning . Rineka Cipta. Jakarta. (2010).

[19] Rahmadani B. The Use of Audio Visual Media to Improve Student Learning Outcomes about Appreciating Heroes' Services (Classroom Action Research in Class V SDN Purwamekar). (2016)

[20] Busyaeri, Akhmad, Tamsik U, A Zaenuddin. The Effect of Using Learning Videos on Improving Learning Outcomes of Science Subjects in Min Kroya Cirebon. (2016).

[21] Buamona S, Lucky T, Kumaat R, T. Malara. The Effect of Health Education on Basic Life Assistance Knowledge (BHD) Levels on Traffic Accidents in High School Students 1 Sanana, Sula Islands District, North Maluku . Nursing e-journal (e-Kp). (2017).

[22] Nursalam. Nursing Process and Documentation. Salemba Medika. Jakarta. (2009).

[23] Notoatmodjo S. Health Research Methodology. Rineka Cipta. Jakarta. (2010).

[24] Dwi, A'an, Gusti ASPWW, Ni PS. Effectiveness of CPR Video on the Capability of Lay People in Performing CPR in Sembung Village, Narmada District. Journal of Prime Health. (2018).

[25] Masfiah S, Elviera G, Arrum F, Adhika P. Effectiveness of Audiovisual Media Training related to Anemia of Pregnant Women in Increasing the Competency of Health Extension Officers in Banyumas Regency . Indonesian Public Health Journal. (2017).

[26] Susilo R. Health Education in Nursing. Nuha Medika. Yogyakarta. (2011).

[27] Rusman. Learning Models. PT Raja Grafindo Persada. Jakarta. (2012).

[28] Nurdyansyah. Resources in Educational Technology. (2017). 